\title{
ASSESSMENT OF THE FINANCIAL STABILITY LEVEL OF UKRAINIAN AGRARIAN CORPORATIONS
}

\author{
Nadiia Davydenko', Prof. dr hab.; Alina Buriak², PhD; Olena Lemishko ${ }^{3}, \mathrm{PhD}$; \\ Zoia Titenko ${ }^{4}, \mathrm{PhD}$ \\ ${ }^{1,2,3,4}$ Department of Finance, National University of Life and Environmental Sciences of Ukraine, Kyiv, Ukraine
}

Abstract. A necessary basis for the functioning, development and achievement of the goals of agricultural corporations in today's crisis environment is the providing of financial stability, the role of which is particularly growing in today's challenging environment. The regular changes of external and internal factors influencing the functioning of economic entities actualize the need to study the components of this category to ensure the ability of the enterprise to adapt while maintaining its integrity.

The purpose of the article is to substantiate theoretical provisions and develop recommendations for ensuring the adequacy and systematic process of evaluating the financial stability of agricultural corporations based on the analysis of financial ratios.

The object of the study is the process of assessing the financial stability of enterprises.

The methodological basis of the article is general scientific and special methods of research, which are based on modern scientific concepts of management, economic and related sciences. The following methods were used in the study: monographic (comparing and detailing the data of financial stability analysis of agrarian corporations); abstract-logical (used to formulate theoretical generalizations and conclusions).

Based on the works of scientists, it is established that the formation of financial stability of agricultural corporations should be based on a comprehensive study of the conditions for its provision, must take into account the features of financial development and the state of agricultural enterprises. A comprehensive study of such issues will solve the problem of financial stability on the basis of organizational support of its management system. The relevance of the assessment of the state of financial stability management in agricultural enterprises is determined, the holding of which is of particular importance due to the possibility of making managerial strategic decisions to improve the management of financial stability.

The article analyszes the financial stability of agricultural corporations. It is substantiated that the unstable financial condition of some agrarian corporations is a consequence of the lack of organization of management of specific subsystems of their economic activity. Throughout the life cycle, enterprises are accompanied by situations that may cause undesirable changes to their financial stability. Therefore, we consider it necessary to implement financial stability management at all stages of the company's life cycle by systematically monitoring the relevant ratios.

The practical significance of the results obtained is determined by the fact that conclusions and suggestions can be used for more objective decision-making, which based on the analysis of financial ratios, and in turn can be the basis for making optimal financial decisions. This material can be used to make strategic management decisions by agro-holding managers.

Key words: stability, financial stability, solvency, financial security, agrarian corporation. JEL code: R14, E22, G21

\section{Introduction}

The financial stability of an agricultural corporation is one of the most important characteristics of its financial potential. It is related to the level of dependence on creditors and investors and is characterized by the ratio of own and borrowed funds.

The issue of financial stability of an agrarian corporation in the face of modern challenges is extremely important, since financial stability is closely linked to the prospective solvency of the 
enterprise. Its analysis makes it possible to determine the financial opportunities of the company in the future.

Assessment of financial stability of an enterprise aims at an objective analysis of the size and structure of assets and liabilities of the enterprise and to determine on this basis the degree of financial stability and independence, as well as the compliance of financial and economic activity of the enterprise with the objectives of its statutory activity (Davydenko N., 2009).

Therefore, achieving a high level of financial stability is a strategic goal of the enterprise in the market, which requires the consolidation of all units and units of its management system. (T. Koritko and V. Dzerzhinskaya, 2008).

Enterprise financial management means the set of interconnected planning, organization, motivation and control processes that ensure the financial sustainability of an enterprise.

Pavlovska V., Prytulyak N. and Nevmerzhitska N. (2007) consider financial sustainability from the standpoint of an enterprise's ability to secure inventories and expenses at its own expense, to avoid unjustified receivables and payables, and to settle liabilities in a timely manner.

Vashchenko L. defines financial sustainability as one of the financial states of an enterprise, which becomes possible only in the presence of specific types, quantities and quality of resources, which are necessary and sufficient to achieve this goal (Vashchenko L., 2005).

The authors agree with O. Kuzmin's opinion that the financial sustainability of an agricultural enterprise is a qualitative characteristic of its financial condition and is characterized as the ability of the enterprise to function and develop effectively, is characterized by a sufficient level of management and financial resources, efficient management of them, which ensures its financial sustainability (Kuzmin O., 2011).

\section{Research results and discussion}

The efficiency and rationality of management decisions depend on the degree of objectivity of the financial state. For effective management of the enterprise, it is important for management to objectively assess the state of the enterprise in a market environment and on this basis, determine the directions and goals of long-term purposes.

The results of the financial analysis can be used by a wide range of users, in particular analysts, investors, banks, creditors, experts on reliability of investments, managers.

At the present stage of development, the scientific theory of management has become even more relevant. It is, above all, characterized by the complexity of the functions and principles that reveal the content of the management process. Financial analysis permeates all management functions and plays an important role in bringing the financial management system into line with the complex tasks of production management. Its results use both informational and reference material when basing and making management decisions. Now in economic theory and in practice, there are several different methodological recommendations on a wide range of indicators that allow to assess the financial state of the enterprise. However, these methods vary in their essence only by the number of indicators used for the analysis and the ways in which they are grouped.

The assessment of the financial state within the context of financial security should be consistent with the following grounds:

- comprehensiveness - the existence of as wide a range of aspects as possible to be considered in measuring the level of financial security. Microenvironment is a complex of integrated system, where the order of formation of financial result is influenced by many factors, which are clearly 
formalized, and subjective. In our view, drawing attention first of all to the financial side of the safe state of operation in the enterprise as an indicator of the state of its development, it is also necessary to clearly define the list of essential features and conditions of economic activity, inherent in the industry as a whole and specifically, the enterprise;

- clarity - the need for a clear interpretation of the results of the assessment of the financial security in the enterprise. The analysis carried out should clearly define the state of development efficiency, financial stability, the viability of insolvency and the overall prospects of subject. Taking into account the different level of training of the user and the provided information, the procedure of presenting the subject to the appropriate level of financial security should be accessible for understanding;

- urgency - is obtained from the terms of the current socio-economic formation of the country. Fiscal policy reforms, the instability of the national banking system and the volatility of solidclimatic factors are the primary cause of the difficult conditions for the management of agrarian subjects. Financial security information should be appropriate and appropriate to the specific temporary and spatial conditions of the activity. In addition, it should be noted that the assessment of the level of financial security should be based on the current achievements of scientific thought;

- veracity and simplicity of computation. Financial security assessments should be based on official financial accountability and should be targeted at a wide range of users. In our opinion, taking into account the above indications to the result of the assessment of the financial security of the enterprise, the latter should be built as a result of the analysis of elements (Fig. 1).

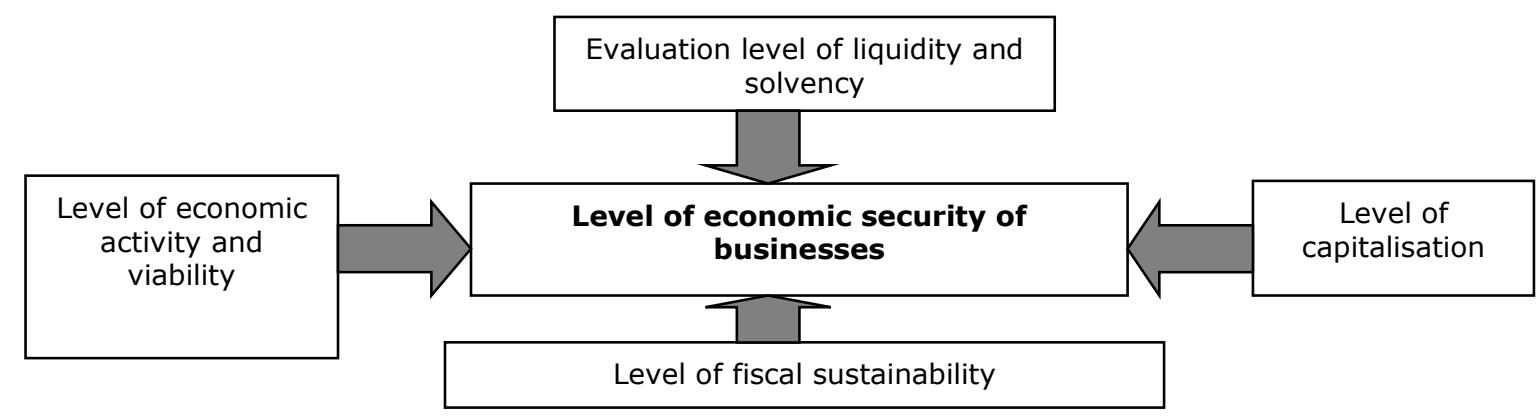

Source: authors' construction

Fig. 1. Evaluation the constituent elements of the financial security of the enterprise

The authors believe that the financial security of the enterprise is an effective result of equivalent components: indicators of financial condition, financial stability and the level of its capitalization.

To ensure the sustainability of the enterprise, it is necessary to ensure sustainable economic growth, which is the ability of an entity to increase production and sales of production, while increasing the efficiency of use of available resources and reducing the impact of external factors on the conditions and parameters of the activity in accordance with the principles of performance. In turn, sustainable economic growth should also be determined by a set of factors and conditions under which these factors will contribute to the achievement of the enterprise's goals for sustainable economic development (Davydenko N., 2006).

The assessment of the financial stability of the enterprise aims at an objective analysis of the size and structure of the assets and liabilities of the enterprise and to determine on this basis the degree of financial stability and independence, as well as the conformity of financial and economic activity of the enterprise with the objectives of its statutory activity. 
According to Blank I., financial stability assessment allows "identify the level of financial risk associated with the structure of sources of formation of the enterprise's capital and accordingly the degree of its financial stability in the process of future development." (Blank I., 2004). That is, financial stability is estimated on the basis of the ratio of own and attracted sources of assets formation of the enterprise, the rate of equity growth due to the economic activity of the enterprise, the ratio of long-term and current liabilities, sufficient provision of working capital by own sources.

Thus, the indicators of financial stability assessment reflect the ratio of varieties of financial resources of the enterprise with each other and to their total value, the degree of mobility of use etc. To assess the financial sustainability of agrarian entities, the authors propose to use solvency ratios, autonomy, financing, equity capital manoeuvrability, and equity ratio.

Thus, the coefficient of autonomy shows the share of own and equivalent financial resources in the total capital of the agricultural entity and characterizes the degree of its independence from the borrowed capital (Table 1).

As higher the value of this ratio, as more financially sound, stable and more independent from external creditors the enterprise is. The recommended value of the coefficient of autonomy is 0.5 (50\%).Accordingly, the total amount of capital must be at least half formed at the expense of the enterprise's own funds, the solvency ratio should be at least 0.5. Thus, in $2006-2018$, the highest rates were observed in Agroton (0.89), Industrial Dairy Company (0.61), Kernel - Trade (0.53). Mironovsky Bakery (0.41), Avangard (0.07) and Ukrprodukt (0.07) were below the recommended values. This indicates a critically low share of equity in the total amount of advanced capital, which makes enterprises financially unsustainable and dependent on borrowed funds.

Table 1

\section{Dynamics of solvency ratio change (autonomy)}

\begin{tabular}{|c|c|c|c|c|c|c|c|c|c|c|c|c|c|}
\hline Companies & \multicolumn{13}{|c|}{ Solvencyratio (autonomy) } \\
\hline Years & 2006 & 2007 & 2008 & 2009 & 2010 & 2011 & 2012 & 2013 & 2014 & 2015 & 2016 & 2017 & 2018 \\
\hline Kernel-trade & 0.05 & -0.01 & 0.003 & 0.02 & 0.02 & 0.62 & 0.56 & 0.57 & 0.54 & 0.61 & 0.66 & 0.57 & 0.53 \\
\hline Agroton & 0.53 & 0.55 & 0.29 & 0.44 & 0.84 & 0.66 & 0.67 & 0.65 & 0.45 & 0.66 & 0.87 & 0.87 & 0.89 \\
\hline Raise-Agro & 0.2 & 0.32 & 0.08 & 0.08 & 0.08 & 0.06 & 0.03 & 0.20 & 0.04 & 0.03 & 0.05 & 0.04 & 0.06 \\
\hline Myronivsky bakery & 0.43 & 0.42 & 0.35 & 0.38 & 0.55 & 0.48 & 0.48 & 0.45 & 0.41 & 0.32 & 0.33 & 0.43 & 0.41 \\
\hline Astarta Kyiv & 0.52 & 0.57 & 0.34 & 0.51 & 0.59 & 0.54 & 0.53 & 0.55 & 0.43 & 0.49 & 0.61 & 0.65 & 0.50 \\
\hline Industrial dairy company & 0.19 & 0.55 & 0.44 & 0.51 & 0.8 & 0.77 & 0.52 & 0.42 & 0.14 & 0.32 & 0.41 & 0.57 & 0.61 \\
\hline Avangard & 0.11 & 0.13 & 0.12 & 0.43 & 0.49 & 0.71 & 0.73 & 0.76 & 0.60 & 0.35 & 0.24 & 0.15 & 0.07 \\
\hline Ukrproduct & 0.59 & 0.68 & 0.71 & 0.80 & 0.75 & 0.62 & 0.57 & 0.55 & 0.43 & 0.27 & 0.16 & 0.14 & 0.07 \\
\hline
\end{tabular}

Source: compiled by the authors on the basis of the financial statements of agricultural holdings

The coefficient opposite to the coefficient of financial autonomy is ratio of financing, the critical value of which is 1 . The coefficient of financing shows which part of the activity of the enterprise is financed at the expense of own funds, and which at the expense of the debt (Table 2). 
Table 2

Dynamics of the coefficient of financing change

\begin{tabular}{|c|c|c|c|c|c|c|c|c|c|c|c|c|c|}
\hline Companies & \multicolumn{13}{|c|}{ Coefficient of financing } \\
\hline Years & 2006 & 2007 & 2008 & 2009 & 2010 & 2011 & 2012 & 2013 & 2014 & 2015 & 2016 & 2017 & 2018 \\
\hline Kernel-trade & -19.47 & -130.6 & 116.47 & 110.71 & 97.51 & 1.69 & 1.30 & 1.32 & 1.16 & 1.55 & 1.94 & 1.35 & 1.13 \\
\hline Agroton & 0.89 & 0.82 & 2.48 & 1.24 & 0.18 & 1.99 & 2.09 & 1.85 & 0.83 & 1.93 & 6.59 & 6.78 & 7.98 \\
\hline Raise-Agro & 13.93 & 12.14 & 12.05 & 11.99 & 11.22 & 7.16 & 4.13 & 0.24 & 0.04 & 0.03 & 0.06 & 0.06 & 0.06 \\
\hline $\begin{array}{l}\text { Myronivsky } \\
\text { bakery }\end{array}$ & 0.29 & 0.46 & 1.88 & 1.63 & 1.51 & 0.93 & 0.91 & 0.82 & 0.70 & 0.48 & 0.50 & 0.76 & 0.7 \\
\hline Astarta Kyiv & 0.93 & 0.74 & 1.93 & 0.95 & 0.67 & 1.18 & 1.12 & 1.21 & 0.77 & 0.96 & 1.60 & 1.87 & 1.02 \\
\hline $\begin{array}{l}\text { Industrial } \\
\text { dairy } \\
\text { company }\end{array}$ & 0.21 & 0.83 & 1.15 & 0.88 & 0.29 & 0.77 & 0.52 & 0.73 & 0.16 & 0.46 & 0.70 & 1.36 & 1.55 \\
\hline Avangard & 5.71 & 6.44 & 7.61 & 1.34 & 2.39 & 2.52 & 2.79 & 3.72 & 1.58 & 0.57 & 0.33 & 0.18 & 0.07 \\
\hline Ukrproduct & 0.27 & 0.36 & 0.41 & 0.25 & 0.33 & 3.07 & 1.64 & 1.34 & 1.22 & 0.75 & 0.37 & 0.07 & 0.16 \\
\hline
\end{tabular}

Thus, according to Table 2, the values of the Kernel-Trade, Agroton, Astarta-Kiev and Industrial Dairy companies' financing ratios are higher, which is indicative of an unstable financial position and high financial dependence on external creditors and investors. The rest of the analysed companies have values lower than 1 , that is, the lowest amount of liabilities per UAH 1 of own funds.

The normative value of the ratio of the security of own working capital is 0.1 and above. High value indicates the financial stability of the corporation and the ability to carry out active activities even in the absence of access to borrowed funds and external sources of financing of the company. Conversely, a value below the standard indicates a significant financial dependence of the enterprise on external creditors (Table 3).

Table 3

Dynamics of change in the ratio of the provision of own working capital

\begin{tabular}{|c|c|c|c|c|c|c|c|c|c|c|c|c|c|}
\hline Companies & & & & & tio of $t$ & provisi & of own & orking & apital & & & & \\
\hline Years & 2006 & 2007 & 2008 & 2009 & 2010 & 2011 & 2012 & 2013 & 2014 & 2015 & 2016 & 2017 & 2018 \\
\hline Kernel-trade & 0.51 & 0.72 & 1.97 & 0.34 & 0.37 & 0.26 & 0.16 & 0.06 & -0.02 & 0.13 & 0.29 & 0.24 & 0.14 \\
\hline Agroton & 0.44 & 0.45 & 0.15 & 0.32 & 3.91 & 0.51 & 0.16 & 0.39 & 0.15 & 0.55 & 0.84 & 0.84 & 0.86 \\
\hline Raise-Agro & -0.12 & 0.15 & 0.09 & 0.30 & -0.37 & -0.57 & -0.70 & -1.58 & -0.69 & -0.35 & 0.04 & 0.03 & 0.04 \\
\hline $\begin{array}{l}\text { Myronivsky } \\
\text { bakery }\end{array}$ & 0.60 & 0.31 & 0.34 & 0.46 & 0.65 & -0.3 & -0.29 & -0.37 & -0.84 & -0.90 & -0.68 & -0.61 & -0.52 \\
\hline Astarta Kyiv & 0.80 & 0.51 & -0.05 & 1.21 & 1.52 & 0.18 & 0.20 & 0.12 & -0.20 & -0.05 & 0.25 & 0.30 & -0.05 \\
\hline $\begin{array}{l}\text { Industrial } \\
\text { dairy } \\
\text { company }\end{array}$ & 0.80 & 0.28 & -0.004 & 0.13 & 2.40 & 0.50 & -0.01 & -0.12 & -0.54 & -0.42 & -0.07 & 0.17 & 0.36 \\
\hline Avangard & -0.18 & -0.49 & -0.23 & 0.12 & 0.26 & 0.42 & 0.30 & 0.31 & -0.01 & -1.08 & -1.75 & -1.68 & -2.17 \\
\hline Ukrproduct & 0.73 & 0.82 & 0.84 & 1.62 & 1.43 & 0.07 & -0.03 & -0.10 & -0.39 & -1.45 & -1.27 & -1.00 & -0.80 \\
\hline
\end{tabular}

Source: compiled by the authors on the basis of the financial statements of agricultural holdings

According to the Table 3, Kernel-Trade, Agroton and Industrial Dairy Company are best provided with their own turnaround businesses, and worst of all: Myronovsky Bakery, Astarta-Kyiv, Avangrad and Ukrproduct.

Equity manoeuvrability ratio shows which part of the equity is in circulation( i.e. in a form that allows these funds to be freely manoeuvred) and which is capitalized. This indicator characterizes the portion of the entity's equity that is the source of coverage of its current assets. To ensure flexibility in the use of the enterprise's own resources, it is necessary that the equity manoeuvrability ratio is positive and high (Table 4). 
Dynamic of equity manoeuvrability ratio change

\begin{tabular}{|c|c|c|c|c|c|c|c|c|c|c|c|c|c|}
\hline Companies & \multicolumn{13}{|c|}{ Equity manoeuvrability ratio } \\
\hline Years & 2006 & 2007 & 2008 & 2009 & 2010 & 2011 & 2012 & 2013 & 2014 & 2015 & 2016 & 2017 & 2018 \\
\hline Kernel-trade & -7.04 & -76.11 & 75.23 & 40.12 & 54.77 & 0.40 & 0.54 & 0.28 & 0.27 & 0.22 & 0.35 & 0.71 & 0.62 \\
\hline Agroton & 0.52 & 0.67 & 0.40 & 0.37 & 0.62 & 0.92 & 0.47 & 0.76 & 0.92 & 1.10 & 0.93 & 0.93 & 0.78 \\
\hline Raise-Agro & -0.36 & 0.35 & 0.67 & -2.84 & -3.20 & & & -2.09 & 0.01 & 0.63 & 2.83 & & \\
\hline $\begin{array}{l}\text { Myronivsky } \\
\text { bakery }\end{array}$ & 0.43 & 0.21 & 0.26 & 0.32 & 0.27 & 0.54 & 0.44 & 0.62 & 0.32 & 0.54 & 0.64 & 0.66 & 0.65 \\
\hline Astarta Kyiv & 0.60 & 0.30 & -0.08 & 0.50 & 0.55 & 0.60 & 0.72 & 0.45 & 0.35 & 0.09 & 0.50 & 0.40 & 0.17 \\
\hline $\begin{array}{l}\text { Industrial } \\
\text { dairy } \\
\text { company }\end{array}$ & 0.92 & 0.16 & -0.003 & 0.08 & 0.28 & 0.46 & 0.37 & 0.19 & 0.65 & 0.26 & 0.78 & 0.45 & 0.51 \\
\hline Avangard & -1.84 & -2.07 & -1.32 & 0.13 & 0.16 & 0.53 & 0.34 & 0.33 & 0.13 & 0.40 & 0.69 & -2.65 & -8.65 \\
\hline Ukrproduct & 0.16 & 0.21 & 0.29 & 0.36 & 0.36 & 0.29 & 0.27 & 0.25 & 0.29 & -0.42 & -2.49 & 0.39 & -0.03 \\
\hline
\end{tabular}

Source: compiled by the authors on the basis of the financial statements of agricultural holdings

The positive dynamics of this indicator is observed in Kernel-Trade, Agroton, Myronivsky Bakery, Astarta-Kyiv, Industrial Dairy Company. Equity manoeuvrability ratio showed positive dynamics in Avangard and Ukrproduct in 2008 - 2013; however, it fell significantly in 2014-2018, which clearly indicates a high deficit of working capital, resulting in a manoeuvrability factor in equity total value.

Thus, according to the results of the conducted analysis, it should be noted that the activity of agrarian corporations in Ukraine is unstable, despite the improvement of some indicators in 20112013. An unstable financial position causes disruption in the balance of payments, although the ability to restore the balance in payment means and payment obligations is retained by attracting temporarily free sources of funds: not expired unpaid wage arrears, unpaid tax payments arrears, unpaid social security debts, unpaid debt on payments with suppliers, etc. However, since the capital in stocks is long enough and the maturities of these liabilities are short, investing in long-term assets causes considerable financial difficulties for the analysed agricultural corporations.

\section{Conclusions}

The financial sustainability of agrarian corporations should be considered as a complex category, reflecting the level of financial condition and financial results of the corporation, the ability to fulfil its obligations and to ensure the development of activities while maintaining creditworthiness and solvency. The condition of the enterprise's viability and the basis for its development in a competitive market is stability. The financial stability of the enterprise is a prerequisite for its economic development.

The results of the study of the state and dynamics of financial stability of agrarian corporations showed that during 2008-2011 and 2016-2018 there was a change in the capital structure towards an increase in the share of equity, which indicates an increase in the level of financial stability.

The largest share of borrowed capital is external capital, which accounts for a large portion of payables, which is reduced in aggregate capital as a result of the increase in the share of own financing, and the share of borrowed capital is slightly higher than its other short-term sources, primarily of a financial nature.

In order to overcome the financial instability of the studied agricultural corporations and strengthen the competitiveness, it is advisable to use a comprehensive approach to improving financial management, whose main focus is in the short term - elimination of insolvency in case of loss of competitive advantages; in the medium term - elimination of causes that generate insolvency and adaptation to the conditions of activity in a competitive environment; in the long term - ensuring the financial stability of the agricultural corporation to the influence of external factors of the competitive environment. 


\section{References}

1. Blank I.A. (2004). Management of Financial Security of the Enterprise. - Kiev. p.84.

2. Davidenko N. M. (2009). Financial Sustainability of Agrarian Enterprise. Topical Problems of Economic Development of the Region: Scientific Collection of Carpathian National University. Vasily Stefanik. No. V. T.2. P.112.

3. Davidenko N. M. (2006). Financial Sustainability of Enterprises and Its Analysis. Scientific Bulletin of NAU. 2006. No.97. Pp.183-187.

4. Koritko T. Yu., Dzerzhinskaya V.N. (2008). Monitoring of financial stability of the enterprise taking into account its life cycle. Bulletin of the Donbass State Machine-Building Academy: Coll. Sciences. wash. No. 3 (13). Pp. $131-134$.

5. Kostyrko, L.A., Kostyrko, R.O., Madiarova, E.S., Sereda O.O. (2018). Complex Analysis of Investment Attractiveness of Enterprises in the Context of Financial Provision of Enterprises Development. Financial and Credit Activity: Problems of Theory and Practice, No 2 (25), pp. 198-207.

6. Kuzmin A.E. (2011). Financial Stability and Profitability as Factors of Formation of Transfer Potential of Innovative Development of the Enterprise. Bulletin of the NBU Banking University. No. 2 (11). Pp. 96 - 103.

7. Pavlovskaya V.O., Prytulyak N. M., Nevmerzhitskaya N.Y. (2007). Financial Analysis. Kiev. p. 211.

8. Vashchenko, L.O. (2005). Information and Methodological Support for the Analysis of the Financial State of Enterprises. State Academy of Statistics, Accounting and Auditing of the State Statistics Committee of Ukraine, p. 8. 